\title{
Experimental Investigation of SCR System for Nox Reduction Using Waste Urea Based Organic Fluid
}

\author{
Kuldeep Vinodkumar Jibhkate ${ }^{1}$, V.W.Khond ${ }^{2}$, Rajendra Kadu ${ }^{3}$, D.S.Deshmukh ${ }^{4}$ \\ ${ }^{1}$ Research Scholar, Department of Mechanical Engineering, G H Raisoni College of Engineering, Nagpur, India \\ ${ }^{2,4}$ Department of Mechanical Engineering G H Raisoni College of Engineering, Nagpur, India \\ ${ }^{3}$ Senior Manager, Mahindra and Mahindra, Nagpur
}

\begin{abstract}
Present study investigated the Selective catalytic reduction exhaust after treatment technology in CI engine to control the NOx reduction. In this study the urea solution are replaced by other waste urea content material. Also some metal oxides are used to reduce the pollution from CI engines. It was observed that low cost natural waste product based SCR solution shows very good capability to reduce emission of diesel engine.
\end{abstract}

Keywords: Natural waste urea based fluid, Exhaust gas emission, SCR, Diesel engine.

\section{INTRODUCTION}

D iesel engines are more porn to oxide of nitrogen and smoke emission. The both emissions are having trade-off between each other[4-8].A EURO-VI norm has the stringent emission norms resulted into focuses towards reduction of NOx and smoke. Selective Catalytic Reduction (SCR) technology very promising technology to control NOx. However, the urea solution required for this technology is hazardous and costly.[911] The water emulsion technology also one method to reduce the NOx emission [12-15]. In previous studies, Ammonia is used in place of urea. However, pure ammonia is toxic and harmful to the human being. Ali Azam et al [1] developed heat exchanger based SCR was developed in a combination with counter flow heat exchanger and also smoke to water heat exchanger with , arrangement of cleaning for oil and exhaust gas recirculation (EGR) for reduction of NOx. Mina Mehregan,
Mohammad Moghiman [2] reports an investigation on combined effects of nano particles dosed fueland urea-SCR system on NOx emissions. They also used the nano-additives effects on emission of NOx and $\mathrm{CO}$ reduction performance of a urea-SCR system is investigated. B20 blended biodiesel of $20 \%$ waste frying oil biodiesel and $80 \%$ diesel blends was used with Manganese oxide and cobalt oxide nano particles with the dosing of 25 and $50 \mathrm{ppm}$ was used. They obtained the significantly affect the NOx emission.Havva H. Ş. [3] reported results of the pollutants ofCI engine using oxygenated additives by using the SCR system. The nano additives of $\mathrm{NiO}, \mathrm{SiO} 2$, and $\mathrm{Zn} 0.5 \mathrm{Ni} 0.5 \mathrm{Fe} 2 \mathrm{O} 4$ along with oxygenated fuel additives on exhaust emissions were investigated. And the They have obtained that $\mathrm{CO}, \mathrm{HC}$, and NOx emissions was reported to be reduced significantly using urea solution and ammonium sulfate salt addition to urea solution. Present study investigate the effect of urea based organic waste material as a reluctant in SCR for reduction of NOx.

\section{II-EXPERIMENTAL SETUP}

The experimental set up consists of SCR system with injection pump as shown in figure 1. Exhaust analyser and smoke meter was used to measure the emission of diesel engine and compared with base diesel.SCR was mounted at the exhaust of the engine and various emission was measured under varying load. 


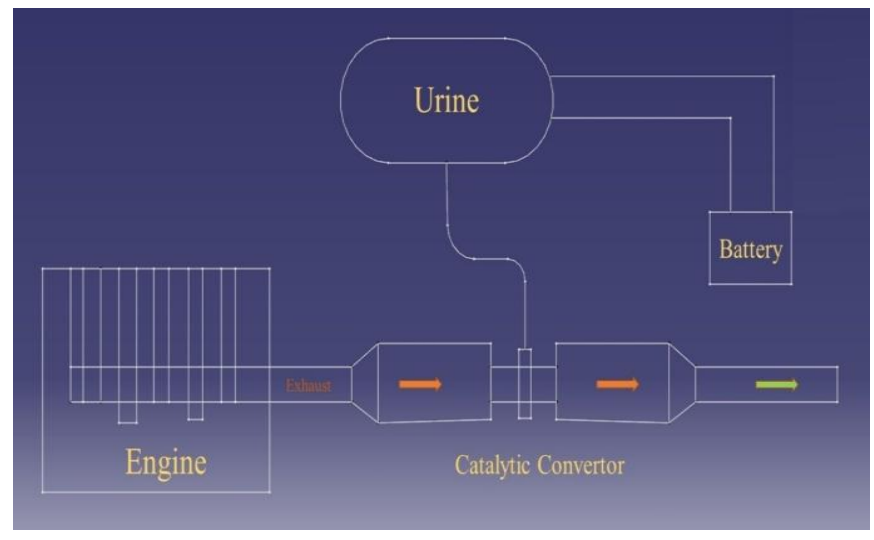

Fig 1- Block diagram of New SCR System

\section{III-METHODOLOGY \& EXPERIMENTATION}

The solution of waste urea based organic compound was mixed with water with concentration $50 \mathrm{ppm}$. The diesel engine started with diesel and without SCR test was carried out. Under the various loads, readings were recorded. Then SCR system was used and with varying the solution of reluctant, reading were taken.

\section{IV-RESULTS AND DISCUSSIONS}

The output obtained from the experiment was shown in table 1 and table 2 to determine the effect of the SCR with new urea based fluid and to obtain the value of corresponding NOx as discussed.

Table 1 Without SCR

\begin{tabular}{|c|c|c|c|c|c|}
\hline Sr.No & $\begin{array}{l}\text { Load } \\
(\mathrm{W})\end{array}$ & $\begin{array}{l}\text { Fuel } \\
\text { Consump } \\
\text { tion }(\mathrm{ml})\end{array}$ & $\begin{array}{l}\text { Time } \\
(\mathrm{Sec})\end{array}$ & $\begin{array}{l}\text { NOx } \\
(\mathrm{PPM})\end{array}$ & $\begin{array}{l}\text { CO } \\
(\% \text { Vol } \\
\text { ume })\end{array}$ \\
\hline 1 & 100 & $5 \mathrm{ml}$ & 39.81 & 170 & 0.03 \\
\hline 2 & 300 & $5 \mathrm{ml}$ & 43.54 & 176 & 0.02 \\
\hline 3 & 500 & $5 \mathrm{ml}$ & 41.16 & 182 & 0.01 \\
\hline 4 & 700 & $5 \mathrm{ml}$ & 40.93 & 188 & 0.01 \\
\hline
\end{tabular}

Table 2: With SCR

\begin{tabular}{|c|c|c|c|c|c|}
\hline Sr.No & $\begin{array}{l}\text { Load } \\
(\mathrm{W})\end{array}$ & $\begin{array}{l}\text { Fuel } \\
\text { Consump } \\
\text { tion }(\mathrm{ml})\end{array}$ & $\begin{array}{l}\text { Time } \\
(\mathrm{Sec})\end{array}$ & $\begin{array}{l}\text { NOx } \\
(\mathrm{PPM})\end{array}$ & $\begin{array}{l}\text { CO } \\
(\% \text { Vol } \\
\text { ume })\end{array}$ \\
\hline 1 & 100 & $5 \mathrm{ml}$ & 45.35 & 165 & .03 \\
\hline 2 & 300 & $5 \mathrm{ml}$ & 43.67 & 169 & .02 \\
\hline 3 & 500 & $5 \mathrm{ml}$ & 42.69 & 175 & .02 \\
\hline 4 & 700 & $5 \mathrm{ml}$ & 41.06 & 179 & .01 \\
\hline
\end{tabular}

\section{CONCLUSIONS}

From the research study it can be concluded that that the distinct SCR system reduces the NOx emission

- Urea based organic substances (which is a composition of Urea and water) acts a good catalyst for the NOx reduction in diesel engine.

- Due to injection of new solution developed for SCR system in the tailpipe NOx reduction was achieved.

- Simultaneously CO also gets decreases.

- With the use of New SCR the most hazardous gases are minimized and Pollution can be controlled significantly. The vehicle performance will be enhanced.

\section{REFERENCES}

[1] A. Azam, A. Naeem Shah, S. Ali et al., Design, fabrication and implementation of HE-OBCU-EGR emission control unit on CI engine and analysis of its effects on regulated gaseous engine emissions, Journal of King Saud University - Engineering Sciences, https://doi.org/10.1016/j.jksues.2019.10.002.

[2] Mina Mehregan, Mohammad Moghiman, Experimental investigation of the distinct effects of nanoparticles addition and urea-SCR after-treatment system on NOx emissions in a blendedbiodiesel fueled internal combustion engine, Fuel, https://doi.org/10.1016/j.fuel.2019.116609

[3] Havva Hande Şahin (2019): Development of a different catalytic oxidation, selection of heavy-duty diesel engines with the use of alternative nanoparticles, Energy Sources,Part A: Recovery, Utilization, and Environmental Effects, DOI: 10.1080/15567036.2019.1671552

[4] S. Gowthaman and K. Velmurugan, "Performance and Emission characteristics of direct injection diesel engine using Bio-diesel with SCR Technology", International Journal of Engineering Research and Applications, (October 2012), Vol.2 issue 5, Pg. 1083-1089.

[5] R. Praveen \& S. natarajan, "Experimental study of selective catalytic reduction system on CI engine fuelled with diesel ethanol blend for NOx reduction with injection of urea solution", vol 6 No 2 Apr-May 2014 (ISSN: 0975-4024)

[6] Xinmei Yuan \& Hongqi Liu, Ying Gao "Diesel engine SCR control: Current development \& future challenges 2015(1:121133) 
[7] Himangshu Sekhar Brahma and Dr.A. Veeresh Babu, "An experimental investigation on emission of neat Mahua biodiesel using urea-SCR", International Journal of Scientific \& Technology Research, (August 2013), Vol.2 issue 8.

[8] C.M.SCHAR, C.H. Onder and H.P. Geering, M Elsener, "Control of a Urea SCR catalytic Converter System for a Mobile Heavy Duty Diesel Engine”, SAE Transactions 2003010776 (2003).

[9] Hünnekes, E., van der Heijden, P., and Patchett, J., “Ammonia Oxidation Catalysts for Mobile SCR Systems," SAE Technical Paper 2006-01-0640, 2006,

[10] Tan, J., Solbrig, C., and Schmieg, S., "The Development of Advanced 2-Way SCR/DPF Systems to Meet Future Heavy-Duty Diesel Emissions," SAE Technical Paper 201101-1140, 2011.

[11] Sinya Sato et al, "The study of NOx reduction using Urea- SCR system for a heavy-duty diesel engine”, 20045293 Proceedings of JSAE Annual Congress (2004).

[12] Khond V.W. and Kriplani V.M., Experimental investigation and modeling of the evaporation rate of carbon nanotube blended emulsified Neem biodiesel, Biofuels, 2019, Vol. 10, No. 4, 485491, https://doi.org/10.1080/17597269.2017.1323322.

[13] Khond V.W. ,Kriplani V.M. An overview of use of Nano-fluid additives in compression Ignition engine fuels (Diesel and Biodiesel), International Journal of Advanced Renewable Energy Research Vol. 2, Issue. 8 pp. 219-233, 2015.

[14] Khond V W, Kriplani V M, Butaley S D, Pitale Amol and Walke Pramod, Experimental analysis of performance and emissions of nanofluid dosed pure neem biodiesel (PNB) — eucalyptus Oil $(E O)$-water (W)-surfactant ( $S$ ) emulsion fuel on Diesel engine, Advances in Energy Research, Vol. 2, Springer Proceedings in Energy, 587-597, https://doi.org/10.1007/978-981-15-2662-6_53.

[15] Khond, V W. Comparative analysis of twin cylinder C.I. engine fueled with diesel and preheated karanj oil, SAE International2013-01-1043 (2013):

https://doi.org/10.4271/2013-01-1043. 